International Journal of Current Aspects in Finance, Banking and Accounting, Volume 4, Issue 1, 2022 PP 35-55, ISSN 2707-8035

\title{
Effect of Ownership Structures on Financial Performance of Listed Manufacturing Firms in Kenya
}

\author{
Stella Kavengi Nzau ${ }^{1}$, Grace Musa ${ }^{2}$ \\ ${ }^{1}$ Student, Master of Science in Commerce (Finance and Investment), School of Business and \\ Public Management, KCA University, Kenya \\ ${ }^{2}$ School of Business and Public Management, KCA University, Kenya
}

\begin{abstract}
Over the last decade, performance of listed manufacturing firms has been deteriorating with some companies almost collapsing. For instance, Mumias Sugar Company and Eveready have shown dismal financial performance. Prior studies have not addressed the effect of ownership structures on financial performance of manufacturing firms in Kenya. The main objective of the study was to determine the effect of ownership structures on financial performance of listed manufacturing firms in Kenya. Specifically, the study sought: to evaluate the effect of board shareholding on financial performance of listed manufacturing firms in Kenya, to explore the effect of foreign shareholding on financial performance of listed manufacturing firms in Kenya, to investigate the effect of institutional shareholding on financial performance of listed manufacturing firms in Kenya, to determine the effect of individual shareholding on financial performance of listed manufacturing firms in Kenya. This study was pegged on five theories; agency theory, stewardship theory, Stulz's Integrated Theory, stakeholder's theory and Resource based theory. This study was undertaken using a descriptive research design. The target population comprised of all seven listed manufacturing firms in Kenya that traded at NSE from 2010 to 2019. The study adopted a census method of data collection. This was made possible using secondary data sheet. Data analysis was undertaken using panel data regression and data analysis results were presented on tables and graphs. The findings revealed that the model linking ownership structures and firm performance was significant. Moreover, the results revealed that foreign shareholding was inconclusive on the effect it has to the financial performance of listed manufacturing firms. Institutional shareholding has negative significant effect on the returns on assets while individual shareholding had a positive and significant effect on firm performance. This study recommended dispersed ownership as it improved financial performance of the manufacturing firms.
\end{abstract}

Keywords: Ownership Structure, Foreign Shareholding, Institutional Shareholding, Individual Shareholding

DOI 10.35942/ ijcfa.v4i1.226

\section{Cite this Article:}

Nzau, S., \& Musa, G. (2022). Effect of Ownership Structures on Financial Performance of Listed Manufacturing Firms in Kenya. International Journal of Current Aspects in Finance, Banking and Accounting, 3(1), 35-55. https://doi.org/10.35942/ijcfa.v4i1.226

\subsection{Introduction}

Corporate owners are the ultimate controllers of firm's resources. Therefore, corporate ownership plausibly influences various perspectives of firm existence. The prime aim of many shareholders is to earn profits by delegating decision making to management (Carney, Estrin, Liang, \& Shapiro, 2019). Firm decisions are made through delegated authority by shareholders to management. Ownership structures depict the ownership of firms be it in form of individuals and corporate. Those who provide equity for firms have the upper hand in making decisions that firm follow in investments. Moreover, those in management are not necessarily the owners and act on delegated authority from owners. Management makes decisions based on what 
International Journal of Current Aspects in Finance, Banking and Accounting, Volume 4, Issue 1, 2022 PP 35-55, ISSN 2707-8035

ultimate owners direct them to hence the notion that management acts on the best interest of those who own and control the firms (Phung \& Mishra, 2016). In essence, this separation of owners and management presents interesting concerns on whether ownership and control play part in firm's financial performance over and above the decisions made by management. Managers are agent of owners of firms and all decisions they make are in line with the directives from owners who have ultimate control (Zhaoyang \& Udaya, 2012). The primary role of control is to create free cash flows and competitive edge in a bid to foster performance of firms (Adamu \& Haruna, 2020). Considering that control of firms lies in the decision of shareholders through the day to day running of operations done by management, the current study is out to assess if there is any effect of ownership structures on performance of listed manufacturing firms in Kenya.

Global literature indicates that various shareholders have different behaviours and influence corporate governance of firms in different ways. Mansur and Tangl (2018 notes that control by shareholders have a bearing on ethical standing of firms and this dictates the direction firms take in respect to management decisions. Moreover, close control of firms by shareholders depends on type of shareholders. Shareholders can propel companies to good practices which ensure that there are cash flows and investments are done in the most prudent manners. According to Gurusamy (2017) the type of owner of a corporate entity is presumed to influence financial performance. For example, institutional ownership is linked to better performance as there is close and skilled control as opposed by control by promoters such as family and friends. Where shareholding is concentrated under promoters, this too may lead to leverage influence and this too has effect on strategic decisions and leverage of firms. Among Italian firms, promoter shareholding does not favour firm financial returns (Bianco \& Casavola, 2016). Among Thailand firms, managerial shareholding, concentrated ownership and family shareholding have proven to be significant determinants of firm's sustainability both in terms of leverage and financial performance(Farooque, Buachoom, \& Sun, 2019).

Firm ownership is a major concern as it has an impact on research and development that in turn affect firm returns. Innovation is a crucial aspect of firm competitiveness as it directly influences level of cost savings. Where owners are able to access R\&D resources, efficiency is likely to be fostered and this can lead to improvement in firm profits. In China, for example, firm ownership structure is construed as a key component that define the innovativeness of firms (Zhou, Gao, \& Hongxin, 2016). In particular, government ownership does not enhance research and development hence rendering the firms inefficient. In situations where owners are innovative, management adopts new ways in production processes and this creates competitive advantages that ultimately increase efficiency (Alabdullah, 2018). Private ownership is often associated with more innovations and this can enhance performance and growth of firms. In this aspect therefore, state ownership fails to offer the efficiency that is so much need to improve performance and keep firms resilient in a competitive global market.

According to Gaur and Delios (2015) there is a direct link between ownership structure and international diversification among firms. International diversification refers to geographical expansion that surpasses the borders of a given country where a firm is domiciled. Firms that have foreign ownership are more likely to engage in international diversification thus facilitating exchange of skills and technology. Among Indian firms, it has been noted that there is a positive nexus between foreign ownership on diversification and this largely affects firm financial results (Gaur \& Delios, 2015). Moreover, where there is so much concentrated local ownership, international diversification may be limited thus impeding on growth and firm performance. Manufacturing firms are prone to stiff competition since in most economic blocs, trade has been liberalized thus allowing free flow of imports and exports. Considering this fact, 
International Journal of Current Aspects in Finance, Banking and Accounting, Volume 4, Issue 1, 2022 PP 35-55, ISSN 2707-8035

international diversification can aid in fostering competitiveness of firm's products leading to survival, growth and sustained profitability.

Firm ownership concentration is viewed as a key component in determining how firms survive financial crisis. Minichilli, Brogi and Calabro (2016) argued that concentrated ownership makes business decision making much more streamlined and this can enhance the results of investments. For example, among Italian manufacturing entities, concentrated ownership through family ownership is pertinent towards improving response to crisis (Minichilli, Brogi, \& Calabro, 2016). This is because consultations is fast and this has the effect of fostering performance. In contrast, dispersed ownership makes decision making a lengthy process limiting the ability to pick up opportunities and respond to threats in a timely manner. Proactive decision making in business is more effective when made at the right time as opposed to prescriptive actions whose impact is seldom felt.

Research carried out in Nigeria established that ownership structures are critical as they provide links between corporate governance and firm stability (Gugong, Arugu, \& Dangago, 2014). This is because the efficiency upon which firm's strategic goals are sought is dependent on how interests of stakeholders are accounted for. For example, managerial shareholding can result to conflicts of interests and this can derail firm activities in pursuit of growth and sustainability of profits. In Ghana, ownership of firms in Ghana has been regarded as key component in financial results as owners have a direct control on corporate governance, what investments firms can undertake and that the different ownership of firms tends to create different agency problems as various owners have a different touch with management (Darko, Aribi, \& Uzonwanne, 2016). Resources equally play an important role in firm performance in different ways. Ownership of resources determines the ability of firms to venture into new markets and also conduct new product development (Lekaram, 2014). In a sector, like manufacturing that has stiff competition due to influx of cheap imports from other regional and global firms, it is critically important for firms to remain competitive. Undertaking competitive advantages require resources, most importantly, financial resources and plant and machinery that are apt and modern to enhance efficiency.

Firms have different innovations capacities and production capabilities depending on their size (Lin, Cheah, Azali, Ho, \& Yip, 2019). Small firms are not able to exploit bigger market considering that an enlarged market require resources to attend to. On the other hand, larger firms are able to undertake more expansion activities thus building a strong competitive advantage as they are able to enjoy economies of scale. Manufacturing firms are involved in various raw material conversion practices in order to turn them into value added products that meet customer expectations (Omesi \& Ogaluzor, 2019). For example, a rise in demand for a certain product only creates a market for a firm if the firm is able to supply additional units as it is required in the market. Productivity and meeting unexpected demand changes are therefore intertwined. Moreover, productivity significantly depends on capacity in form of plan and machinery, human resources and financial resources.

Typically, for a manufacturing firm, firm size is proxied by total assets ownership (Kartikasari \& Merianti, 2016). Total assets refer to all non-current and current assets. Assets are things of value that are used to provide a service or to provide an asset for the case of manufacturing entities. Essentially, larger firms are able to dominate markets for several reasons. To start with, larger firms are more likely to access financial credit than it is for smaller firms. Large firms have assets that can be charged to secure institutional loans enabling them to use the credit proceeds in acquiring robust technology to use in production processes (Simiyu \& Too, 2018). Secondly, larger firms are an attraction to skilled workers as individuals would wish to work 
International Journal of Current Aspects in Finance, Banking and Accounting, Volume 4, Issue 1, 2022 PP 35-55, ISSN 2707-8035

for large firms due to security of tenure. This improves efficiency of production process as time and costs for production runs are significantly reduced.

Larger firms are inclined to having better managerial resources and organisational planning hence enabling them to exploit new markets in a timely fashion. In this aspect, firm size can play a role in firm performance (Eyigere, 2018). Manufacturing firms around the globe are key contributors to economic growth and development in various folds. These firms are important in making use of natural resources and other primary resources through conversion into more valuable forms. In Vietnam, manufacturing is important in expansion of trade within the country and also for earning foreign exchange through exports (Chih-Hai \& Huang, 2016). In absence of a stable manufacturing sector, most resources would remain idle. A country that does not focus on improving manufacturing sector more often has a deficit in balance of trade as imports are more than exports. In realization of this, the way manufacturing firms undertake activities is of value to firms as it depicts on how best resources are used to make products. Barnabe and Ming (2020) argue that manufacturing firms are primary drivers of technical efficiency by engaging in Research \& Development activities. Research indicates that manufacturing firms contribute to more than seventy percent of innovations in the business sector. The benefits of these innovations enjoyed within the sector and outside the sector.

According to Beneito, Maria and Amparo (2015) manufacturing firms in Spain play a major role in research and development. This is because, in the quest to improve efficiency, manufacturing firms adopt new technologies that improve on quality of products, reduces wastages and saves on time for production processes. In addition, manufacturing firms are a market to raw materials producers. At the same time, manufacturing firms provides employment opportunities to a lot of workforces in both developing and developed economies. This observation has equally been noted among Chinese firms in which it is construed that manufacturing firms are key drivers of technological improvements (Barnabe \& Ming, 2020). Technical efficiency started by manufacturing firms gets diffused to other sectors of the economy thus improving the overall technology statuses in a country.

Listed companies in Kenya are grouped into four categories where we have Agriculture, commercial and services, financial and industrial and allied. In Kenya, under the category of manufacturing and allied, firms whose shares are available for public trade are nine namely, British Oxygen Company (BOC), British American Tobacco Company, Mumias Sugar Company, Carbacid, East African Breweries, Unga Group Limited, Kenya Orchards Limited, Eveready East Africa Limited and Flame Tree Group Holdings Limited(Nairobi Securities Exchange, 2021). It is expected that attainment of high financial performance by Kenya's manufacturing companies would call for proper ownership structures. Achievement of this would be made possible by assessing the effect of board shareholding, foreign shareholding, institutional shareholding and Individual shareholding and on financial performance of listed manufacturing firms in Kenya.

The main aim of the current study is to assess the effect of ownership structures on performance of listed manufacturing firms in Kenya. This study has been necessitated by the fact that over the last decade, performance of listed manufacturing firms has been deteriorating with some companies almost collapsing. For example, Mumias Sugar Company has incurred losses of Kenya Shillings 15 billion and 6 billion for the year ended 31st December 2018 and 2017 respectively (Capital Markets Authority, 2019).Another listed manufacturer, Eveready East Africa has reported losses of Kenya shillings 115 million and 167 million for the years 2019 and 2018 respectively(Eveready East Africa, 2020). 
International Journal of Current Aspects in Finance, Banking and Accounting, Volume 4, Issue 1, 2022 PP 35-55, ISSN 2707-8035

Equally, BOC Kenya has showed a decline in profits from Kenya shillings 101.7 million to 75.6 million in the financial year 2018 and 2019 respectively (BOC kenya 2020). Another company Frame Tree Limited equally has reported losses to the tune of Kenya Shillings 37 million and 8 million in financial year 2019 and 2018 respectively (Frame Tree Group 2020). The trend has been similar to most manufacturing firms in Kenya. This situation therefore calls for assessing the effect of ownership structures on performance of listed manufacturing firms in Kenya.

\subsection{Literature Review}

\subsection{Theoretical review}

A theory is primarily a postulation that explain something. Theories attempt to justify occurrence. Theories focus on substantiating why phenomenon and idealizes on what ought to happen in different situations. In research theories describe variables and aid in formulation of hypothesis in what is tentatively expected by interaction of variables (Kochen, 2014). This study is pegged on four theories; agency theory, stewardship theory, Stulz's integrated theory, stakeholder's theory and resource-based view theory.

\subsubsection{Agency Theory}

Agency theory originated from scholarly works of Jensen and Meckling (1976) who identified that in the business realm, those making routine decisions do so through delegated authority from some other people. This theory identifies three critical aspects in its discourse; agents, principals and agency problem. As per this theory, a principal is that entity or person with topmost authority and controls the overall decisions undertaken. In corporates' management, by virtue of principals being investors who may contribute capital but with no much knowledge on business management, they hire managers to work for them.

An agent is the one whose authority is delegated to which then means that the decisions they make are within the powers conferred to them by principals (Brahmadev \& Leepsa, 2017). An agent has interests and so does the principals (owners) and this creates agency problem. Agency problem can be defined as divergence of activities by agents. Several studies have been anchored on this theory. Gurbuz and Aybars (2010) used this theory to study foreign ownership and firm performance in Turkey. This study equally examines foreign shareholding and other shareholding parameters on firm performance among listed manufacturers in Kenya. Bjurstrom and Schillemans (2020) used agency theory to study on corporate governance while this current study uses this theory to examine shareholding of firms and its effect of firm financial performance.

Chrisman (2019) criticized this theory based on its practical application while in this study, this theory is deemed relevant. Feng, Wei, and Zhu (2018) used agency theory to focus on role of shareholders in innovations while in this study, the focus was to examine shareholding constructs on financial performance. Though agency theories have received wide acceptance, it has its own flaws. To begin with the assumption that at all times principals and agents are in conflicts is not always true (Parker, Dressel, Chevers, \& Zeppetella, 2018). At times, principals and agents are in agreement and therefore the agency problem ceases to exist. Where there is no difference in risk preferences, the tenets of agency theory do not hold and thus not feasibly applicable. Therefore, this simplistic approach renders the theory impractical to apply in all situations. Moreover, agency theory does not apply to firms whose owners are the managers as this does not result into any divergent of goals. Considering this scenario, agency theory may not be applied to firms with concentrated ownership. Moreover, this theory fails to account for interest of other parties such as employees and the government in formation of solutions to agency problem (Yusuf, Yousaf, \& Saeed, 2018). 
International Journal of Current Aspects in Finance, Banking and Accounting, Volume 4, Issue 1, 2022 PP 35-55, ISSN 2707-8035

Agency theory has been used in this study because of three reasons. First, it identifies those managers and owner in big firms are not always in agreement with each other in respect to investments decisions, risk and return preferences and information in possession. Agency theory posits that it is the influence of management and owners' goals that sustain companies' profitability and growth. Secondly, agency theory indicates that shareholding could influence performance of firms. Lastly, this study endeavors to explore role of ownership structures from ownership point of view and their effect on financial performance.

\subsubsection{Stewardship Theory}

Davis and Donaldson (1991) coined this theory to explain management and control behaviors in an organization. This theory is pegged on the premise management desire to work as stewards and if they are allowed power to utilize resources, they act in the best interest of all stakeholders. In this postulation, a steward is a party that manages resources on behalf of others and this is done in good faith. Stewardship theory closely connects with agency theory except that it does not have similar assumptions and considers more stakeholders other than managers and shareholders (Chrisman, 2019). In this theory, managers are construed to be rational and collectivist persons who seek the best for the organization and others with interest in the organization. Stewardship theory view that managers are dominantly hired to safeguard, protect and expend resources on behalf of the organization (Feng, Wei, \& Zhu, 2018).

Omesi and Ogaluzor (2019) used this theory with the focus being firm performance among goods manufacturers in Nigeria while this theory is used to focus on shareholding and financial performance of listed manufacturers in Kenya. Ndiba (2016) used this theory to study sugar manufacturers in Kenya while in this current study all listed manufacturers in Kenya are considered. Lekaram (2014) used this theory to focus on corporate governance of listed firms in Kenya. However, in this current study, the focus is on shareholding and financial performance. Kobuthi, K'Obonyo and Ogutu (2018) used stewardship theory and focused on corporate governance while this current study uses it to examine shareholding and firm performance.

In spite of steward theory proving immensely valuable in discourse on ownership, control and management, it has a number of criticisms. The main one is embedded in the assumption of trust from owners and managers that they all work in a trustworthy pro-socio manner (Feng, Wei, \& Zhu, 2018). This is practical in the modern business environment characterized by market competition, regulations and competition for resources. Stewardship theory advocates for an honest approach to management and ownership in a bid to foster performance. The view that honesty can be realized is also not an easy fete and it is not always safe to leave managers on their own as they may embezzle funds leading to collapse of businesses. The powers of managers ought to be restricted in order to ensure that interests of all stakeholders are taken care of (Schillemans \& Bjurstrom, 2020). Stewardship theory is pertinent and relevant to this study because this study examines various aspects of shareholding on financial performance. In this study, the variables being assessed are board shareholding, foreign shareholding, institutional shareholding and individual shareholding on firm performance. Shareholding cannot be discussed without mentioning ownership structures and therefore this makes stewardship theory important in this study. Moreover, stewardship theory presents an interesting utility function for control and trust among managers and shareholders.

\subsubsection{Stulz's Integrated Theory}

Stulz (1988) developed this theory with the aim of explaining how ownership structures influences firm's performance. The theory is pegged on the premise that controlling shareholders have a chance and tendency of selfishly using their powers to gain self-interests at the neglect of the outside shareholders. Moreover, this theory places an argument that agency 
International Journal of Current Aspects in Finance, Banking and Accounting, Volume 4, Issue 1, 2022 PP 35-55, ISSN 2707-8035

problem is more pronounced when there is diffusion in ownership. As such, concentrated ownership seeks to reduce the agency problem thus promoting firm's ability to make better investments decisions (Serfling \& Juan, 2014). This theory further postulates that management or board owned equity has a hostile takeover bid by investors who desire to control such a firm. On the reverse, where management owns few shares, hostile takeover is seldom. It therefore means that there exists a curvilinear function between insiders share ownership and firm value. This theory also posits that an increase in board shareholding is likely to improve firm financial performance, given that board and management would work extra hard to rule out a chance for hostile takeover (Malla, 2013).

Salehi and Baezegar (2011) argued that increase in ownership of equity shareholding by management significantly reduces the possibility of a hostile takeover of a firm however the theory does not address the scandals that are associated with majority of the corporate firms not forgetting the dismal performance in the manufacturing industries in developing economies. It can also be argued that insiders or majority shareholders in a firm can transfer the value from external investors to themselves thus creating a conflict between them and the minority shareholders. This conflict however is limited by the amount of equity that majority shareholders can raise from external investors. This affects the decisions to be made in the corporate firms. These decisions will be influenced by the ownership stakes in the firm thus affecting the firm performance. At the international level ownership concentration inversely limits a country and multinationals to benefit from financial globalization thus affecting their financial performance (Stanley, 2007). To cancel out the agency problem for listed firms, this theory views that control should be diffused, for instance, by listing shares to foreign shareholders and listing in foreign exchange markets. This in turn would increase profitability of firms. Stulz's theory is relevant to this study as it expressly links control and ownership structures on firm value and performance. The theory indicates that concentration of control does not favor performance. This theory therefore is focal in understanding all independent variables and their role in firm performance.

\subsection{Empirical Literature Review}

This part presents a discussion of studies done in the field of control and ownership of firms in order to establish research gaps and infer on hypothesis. This section is arranged as per the objectives.

\subsubsection{Board Shareholding and Financial Performance}

Board shareholding is theoretically expected to improve firm performance as the board members are inclined to making more informed and better decisions since this affects the networth of shareholders of which they are also members. Board of management is charged with the responsibility of running companies by making strategic decisions. Survival of firms largely depends ondecisions made by those in management. Whole time directors participate in day to day running of firms. Saidu and Gidado (2018) examined the effect of managerial ownership on the financial returns of the listed manufacturing companies in Nigeria. In this study, the main goal was to evaluate whether management shareholding affects firm profits. Data in this study was obtained from the reports of forty manufacturing firms listed in the Nigeria Stock Exchange markets reported annually.

The data obtained was then subjected to correlation and regression models for the purpose of analysis. In this study it was concluded that managerial ownership affects the performance of the firm's financial performance negatively. The study focused on managerial ownership while this current study uses more aspects of shareholding. Moreover, the current study followed panel data analysis.Farooque, Buachoom and Sun (2019) purposed to evaluate the impacts of audit committee features, corporate board and the structure of ownership of the listed firm's 
International Journal of Current Aspects in Finance, Banking and Accounting, Volume 4, Issue 1, 2022 PP 35-55, ISSN 2707-8035

performance financially in Thailand. Data was sourced from a sample of the 452 firms listed in the stock exchange market. Ordinary Least Squares (OLS) was employed for the purpose of data analysis. The conclusion of the study was that managerial ownership had a significant impact on the financial performance of the firms. The research gap that this study seeks to fill is methodological gap since the current study focuses on panel data regression. Guo and Kumara (2012) aimed at examining the relationship between the performance of the listed firms in Colombo stock exchange and the structure of governance in Sri Lanka. Data was obtained from 174 firms in the 2010 financial year and then subjected into multiple regression analysis. It was found out that the size of the firm and director shareholding had a significant and positive relation on performance of the firms. Whilst this study yields useful insights, the use of simple OLS limits its efficacy. The current study used panel data analysis and the predictors were shareholding constructs with firm size as moderating variable.

Mandala, Kaijage, Aduda and Iraya (2018) investigated if there exists a correlation between the structure of board of a firm and performance of Kenyan firms. The specific objective was to examine the role of board size, board composition, CEO duality, board activity, board diversity and board type. Firm performance was proxied by return on assets and revenue growth rates. Data collection sheets were used for the financial institutions for a period of ten years from 2006 to 2015. A generalised estimation equation, correlation and regression analysis were used for the process of data analysis. It was revealed that the structure of the board had an independent relation on the influence on the executions of the financial institutions. On board shareholding, results showed positive but insignificant influence on return on assets and revenue growth. This study mixed corporate governance constructs and ownership structures while the current study narrowed down to shareholding aspects. Vu, Phan and Le (2018) analysed the relationship between the board ownership structure and the financial performance of the firms in Vietnam. An empirical study of 557 firms listed in the Vietnam stock exchanges was carried out and then subjected to regression analysis model for the final conclusions. The number of board of directors, the CEO ownership and the ownership concentration in board of directors had a positive influence on the return on assets but no significant impact on return on equity. In this study, the focus was on various shareholding constructs.

\subsubsection{Foreign Shareholding and Financial Performance}

Foreign shareholders are an important source of new skills and production methods through technology. Foreign shareholders exert governance pressure to management which leads to efficiency. It is expected that the presence of foreign shareholders improves performance. Foreign shareholders bring foreign direct investments to firms and this increase firms' capacity to invest. Thus, foreign shareholders improve firm performance. Mihai and Cosmin(2013) carried out research to examine the link existing between the foreign ownership and performance of manufacturing firms in Rome. Data used in this paper was obtained from the Amadeus databases and Bucharest Stock Exchange markets. Linear regression model was adopted in the data analysis process. In this study, a large sample of two hundred and sixtyone entities was used from which raw data was obtained. Results of data analysis revealed that foreign ownership has insignificant influence on firm performance. In this current study, methodology used was panel data regression in which Hausman tests for random and fixed effects was specified in order to improve the efficacy of the regression.

Kao, Hodgkinson and Jafaar (2019) assessed the impact of ownership structure and board of directors on the value of the firm in Taiwan. Secondary data from Taiwanese listed firms was used in this study. Raw data was extracted from firm reports for the period between years 1997 and 2015. The data was subjected to ordinary least squares regression model for the purpose of getting inferences. Upon data analysis, it emerged that where the proportion of independent 
International Journal of Current Aspects in Finance, Banking and Accounting, Volume 4, Issue 1, 2022 PP 35-55, ISSN 2707-8035

directors and size of the board is smaller, the stronger the performance of the firm. Moreover, the findings inferred that block holder's shareholding, family shareholding, institutional shareholding and foreign shareholding positively influences firm value.

The current study differs from this in terms of conceptual and methodological gap. This study used panel data regression and had more explanatory variables. Gurbuz and Aybars (2010) explored the effect of foreign ownership on the on the financial performance of the companies listed in Istanbul stock exchange in Turkey. Panel data analysis was carried out on a sample of 205 non-financial listed companies from 2005 to 2007. It was concluded that foreign ownership of a firm improves the performance of the firm financially. The study majored on one predictor while the current study had four input variables and one moderating factor. Moreover, the current study takes a sectoral outlook as it focuses on listed manufacturers in Kenya.

Adamu and Haruna (2020) evaluated the relationship between ownership structure and the performance of the listed non-financial firms in Nigeria. Secondary data was collected from a sample of forty firms. Canonical correlation was used in the analysing of data obtained. It was revealed that foreign ownership, institutional ownership and ownership concentration had a positive relationship with the performance of the firms financially while managerial ownership had a negative correlation. Use of ordinary least squares regression limits the efficacy of the estimates. This current study bridges this methodological gap by employing panel data regression. Thai and Kabir (2017) focused on firm traits and how they influenced firm performance. The study purposed to investigate on the effect of corporate social responsibility, foreign ownership, state ownership and board constructs such as size and independence. In terms of data and methods, the focus was on a sample of listed entities in Vietnam. Data was processed by undertaking a robust regression analysis, fixed effects model and ordinary least squares regression. The results evidenced that firm performance improved in presence of foreign ownership, an independent board and a large board. In contrast, the results indicated that state ownership neither supports firm performance nor corporate governance. Wang and Wang (2015) focused on foreign ownership and its role on productivity and firm performance in China. This study used data that was collected from firms that had foreign ownership and domestic ownership. Data analysis revealed that foreign ownership improves various aspects of firms such as productivity, employment terms and ultimately favours firm performance. Moreover, the study revealed that foreign ownership significantly improves financial stability of firms in China.

\subsubsection{Institutional Shareholding and Financial Performance}

Institutional shareholders are firms and corporates that have shares in other firms. Institutions have a strong control on the companies they invest in. Other firms are able to provide oversight on operations of other firms. Thus more concentrated institutional shareholders are expected to improve performance. Gugong, Arugu and Dandago (2014) investigated the effect that ownership structure has on the performance of the insurance firms in Nigeria financially. This review had two predictor namely managerial ownership and institutional shareholding. A panel data set was collated from 17 firms between the years 2001-2010. Regression analysis was used for the analysis of the data gathered. It was revealed from the research analysis that there exists a positive relationship between return on asset, return on equity and managerial shareholding.

Also, there was a significant positive influence of institutional shareholding on firm performance of the insurance firms. Whilst this study is vital, the key limitation is that only two predictors were used. My study has four input variables. Gurusamy (2017) undertook a study whose main goal was to report on effect of corporate governance on financial performance of Indian firms. The study was a case of the manufacturing firms in Bombay Stock 
International Journal of Current Aspects in Finance, Banking and Accounting, Volume 4, Issue 1, 2022 PP 35-55, ISSN 2707-8035

Exchange. From a sample of three hundred and fifty-seven entities a panel data set was collated. A regression analysis from the data sourced from years 2006 to 2015. The researchers found out that promoter's shareholding is significantly and negatively related to return on assets and also return on equity. Also there exists a negative relation between institutional shareholding and financial performance of firms. The current study had more variables and uses a different kind of methodology that is panel data analysis as opposed to simple multivariate regression analysis. Mansur and Tangl (2018) examined the impact of corporate governance on the financial performance of the listed companies in Amman Stock Exchange in Jordan. This paper was based on the analysis of the previous Jordanian studies on corporate governance. It was revealed that institutional shareholding has more positive effect on the performance of the firm's financially more than family ownership. The study majored on corporate governance. To the contrary, the current study deals with board shareholding, foreign shareholding, institutional shareholding and individual shareholding and firm performance.

\subsubsection{Individual Shareholding and Financial Performance}

Individuals shareholders often do not have the capacity to control management decisions as it for the case of institutional and foreign shareholders. Individuals shareholders are scattered all over thus do not have a force to intil strict corporate governance practices to management. They are only involved in decision making at the annual general meeting. Thus a high concentration of individual shareholding is expected to lower performnace. Phung and Mishra (2016) did a study in Vietnam that sought to establish ownership diversity and firm financial returns. In this study, the variables were foreign ownership, state ownership and individual ownership. Data was collected from a sample of listed entities and analysis was done using panel regression. The results revealed that foreign ownership boosts performance while state ownership and individual ownersip does not improve firm performance. The study advocated for foreign investor in order to foster firm financial performance.

Chandrasena and Kaluthunga (2015) evaluated ownership structure and firm performance in Sri Lanka. Their study focused on listed entities and the objectives were to establish whether insititutional ownership, individual ownership and concentrated ownership influence firm financial performance. The study used data that was extracted from annual reports of listed entities for a period of five years and perfomed panel regression. Results revealed that insititutional ownership improves firm'sfinacial performance while individual ownership hampers firm results. Additionally, findings showed that concentrated ownership boost performance significantly. Mudi (2017) undertook a study that sought to establish share ownership and firm performance. In this study, the specific goals were to evaluate role of managerial shareholding and individual shareholding on financial performance. Data was analysed using a regression analysis after summarizing data from CMA extracts and firm's annual reports. Results revealed that both individual shareholding and managerial shareholding are significant determinants of firm financial returns. Moreover, both constructs were noted to positively influence performance of listed entities at the NSE in Kenya. The current study expands the conceptual scope by including foreign shareholding in the estimation model. Moreover, a different methodology, panel data analysis, is used. Gichohi (2018) focused on ownership of equities and performance of listed firms at the Nairobi Securities Exchange in Kenya. This study had for constructs of shareholding namely government ownership, local ownership foreign ownership and managerial ownership. Regression results showed that only foreign ownership was significant in influencing performance. Moreover, results indicated that local ownership negatively and insignificantly influenced performance of listed entities in Kenya. This study used simple multivariate regression while the current study used panel data regression in a bid to estimates the model relating shareholding and firm performance. 
International Journal of Current Aspects in Finance, Banking and Accounting, Volume 4, Issue 1, 2022 PP 35-55, ISSN 2707-8035

\subsection{Conceptual Framework}

A conceptual framework illustrates how variables in a given study are interlinked (Tamene, 2016). The conceptual framework of this study is presented on Figure 2.1. The independent variables are; board shareholding, foreign shareholding, institutional shareholding and individual shareholding.

\section{Independent Variables}

Dependent Variable

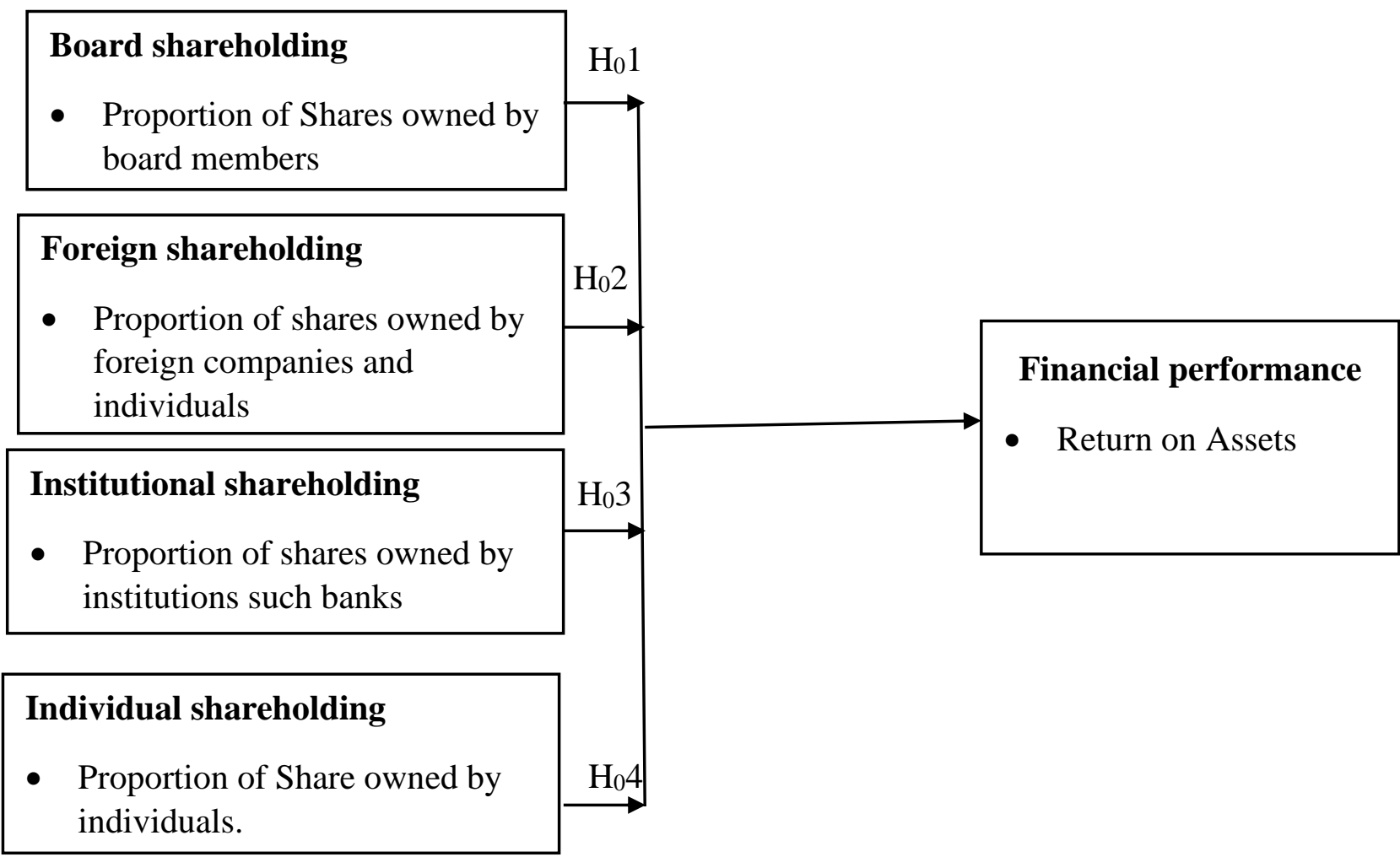

Figure 1: Conceptual Framework

\subsection{Research Methods}

This study was undertaken using a descriptive research design. Considering that this study seeks to assess shareholding and performance of firms, descriptive design is the best framework as this study sought to assess role of shareholding on firm performance. A descriptive research design purposes to ascertain whether there is a link between explanatory and regressor variables and also tells whether the link is statistically significant or not (Cooper \& Schindler, 2014). The target population were all listed manufacturing firms in Kenya. According to NSE (2021) there are 7 listed manufacturing entities in Kenya that traded from 2010 to 2019.Considering the small number of listed manufacturers in Kenya, this study carried out a census of listed manufacturers at the NSE.

This study used secondary data from firm's records and reports. A secondary data sheet was prepared on Excel where the researcher keyed in observations of each variable for every company. There were four predictors in this study (board shareholding, foreign shareholding, 
International Journal of Current Aspects in Finance, Banking and Accounting, Volume 4, Issue 1, 2022 PP 35-55, ISSN 2707-8035

institutional shareholding and individual shareholding). The regressor variable was firm performance. The study obtained data for every listed manufacturer for a period of six years for the year 2010 to 2019 . The process of getting the field data began with getting authority to conduct the research from the graduate school at KCA. The second phase entailed getting the annual reports from the firms' website. Two main types of data analysis were undertaken in this study: descriptive statistics and panel data analysis. Exploratory data analysis was done for the dependent variable in order to examine whether time variant fixed effects were present. Reporting on hypothesis was achieved by undertaking data analysis using panel data regression. Panel data has observations for a panel of firms in different times. In this study, data was collected for the seven firms from 2010 to 2019. Thus, the panel variable was firm 1 to firm 7 while the time variable was year 2010 to 2019. This subsequent section presents the step-by-step discussion of data analysis.

Data analysis was undertaken using the steps adopted in panel data analysis. STATA version 16 was used in data analysis. The function linking the hypothesised relationship between shareholding structures and financial performance is shown as:

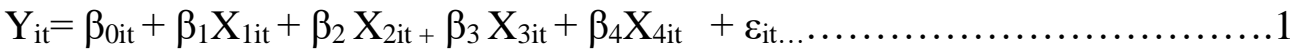

Y: financial performance of listed manufacturers in Kenya, (ROA)

$\mathrm{X}_{1 \text { : board shareholding }}$

$\mathrm{X}_{2}$ foreign shareholding,

$\mathrm{X}_{3:}$ institutional shareholding

$\mathrm{X}_{4:}$ individual shareholding

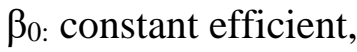

$\beta_{1}$ is coefficient estimate showing effect of board shareholding on financial performance,

$\beta_{2}$ is coefficient estimate showing effect of foreign shareholding on financial performance,

$\beta_{3}$ is coefficient estimate showing effect of institutional shareholding on financial performance,

$\beta_{4}$ is coefficient estimate showing effect of individual shareholding on financial performance,

$\mathrm{t}$ is time variable, 2010 to 2019 ,

$\mathrm{i}$ is cross sectional unit, 1-7 for each listed manufacturing firm in Kenya and $\varepsilon$ is the error term.

In this study, hypothesis was tested at confidence interval of $95 \%$ in which level of significance is 0.05 . This means a p-value of less than 0.05 would lead to rejection of null hypothesis in favour of alternative hypothesis for a particular test. Data analysis was done using STATA as it is a good tool with various modules for transformation of data depending on what is required. Data analysis results were presented on tables and using graphical methods.

\subsection{Data Analysis Results}

This study sought to establish the effect of ownership structures on financial performance. The model was fitted using the random effects model after treating the Serial Correlation. This was done by regression of AR and generated the final output or results as shown below. 
International Journal of Current Aspects in Finance, Banking and Accounting, Volume 4, Issue 1, 2022 PP 35-55, ISSN 2707-8035

\section{Table 1: Model Fitting Coefficients}

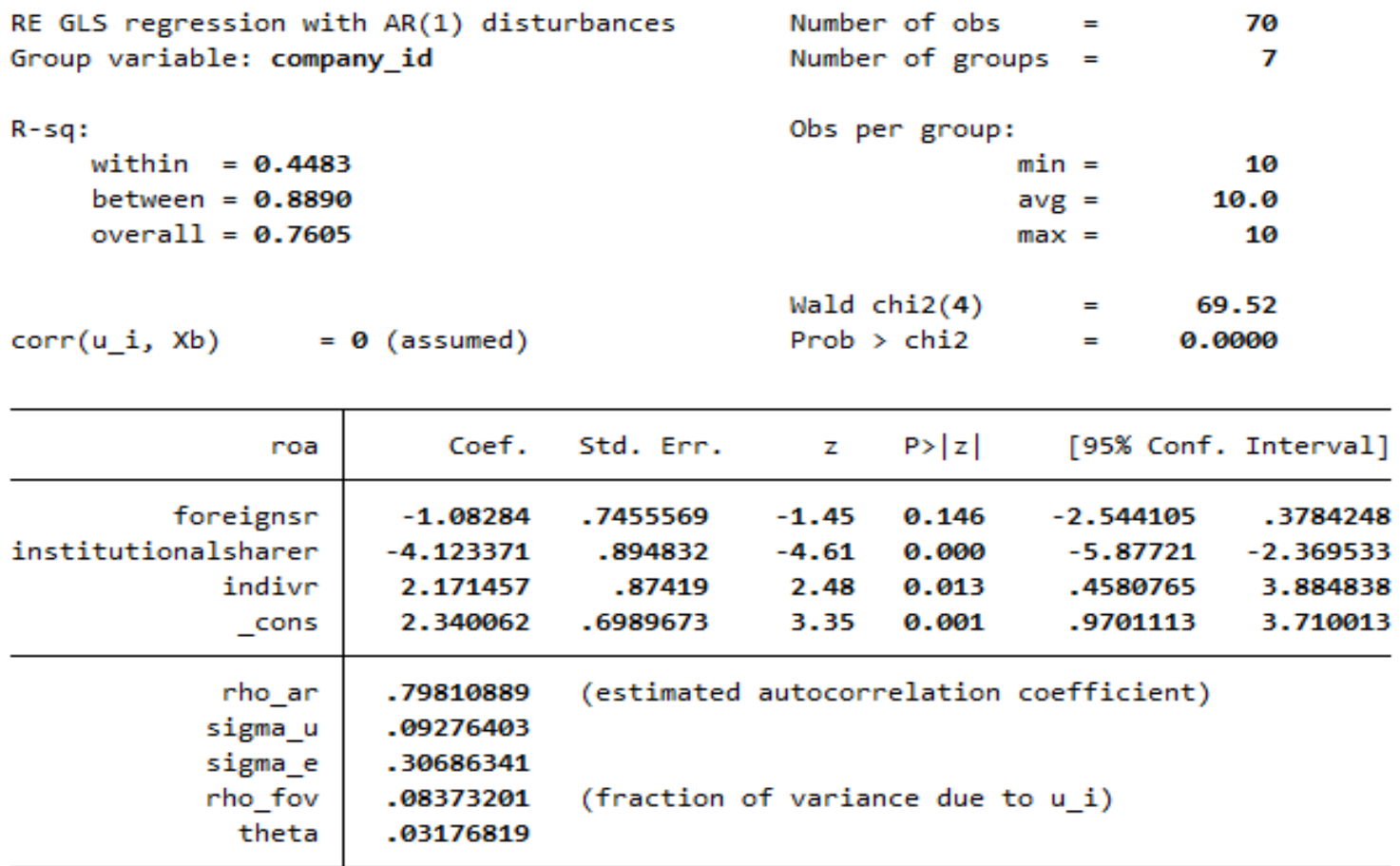

Source: Data Analysis Output (2021)

The original mathematical model is illustrated below which was transformed in order to fit the final model.

$$
Y=B_{0}+B_{1} X_{1 i t}+B_{2} X_{2 i t}+B_{3} X_{3 i t}+B_{4} X_{4 i t}+\varepsilon_{i t}
$$

\section{Equation 1: Fitted Model}

Where,

$Y=$ Financial Performance as measured by Return on Asset

$B_{0}=$ Constant, $B_{1}, B_{2}, B_{3}, B_{4}$ are the coefficient of the dependent variables

$X_{1}=$ Foreign Share holding

$X_{2}=$ Institutional Share holding

$X_{3}=$ Individual Share holding

$X_{4}=$ Board Share holding

$\varepsilon_{\mathrm{it}=\text { Error Term }}$

The above original model was transformed after running the diagnostics whereby multi collinearity was detected between board shareholding and foreign shareholding and as result Board shareholding was dropped completely from further analysis. This reduced the independent variables to three thus necessitating review of the final model as shown below.

\section{Equation 2; Revised Equation}

$$
Y=B_{0_{i t}}+B_{1} X_{1_{i t}}+B_{2} X_{2_{i t}}+B_{3} X_{3_{i t}}+e_{i t}
$$

Where,

$Y=$ financial Performance as measured by return on Asset 
International Journal of Current Aspects in Finance, Banking and Accounting, Volume 4, Issue 1, 2022 PP 35-55, ISSN 2707-8035

$B_{0}=$ Constant, $B_{1}, B_{2}, B_{3}$, are the coefficient of the dependent variables

$X_{1}=$ Foreign Share holding

$X_{2}=$ Institutional Share holding

$X_{3}=$ Individual Share holding

The final model was fitted as follows based on the results above

$$
Y=2.34-1.08 X_{1}-4.12 X_{2}+2.17 X_{3}
$$

The fitted regression model above was fitted based on the results of the table above on Random Effects after treating serial correlation. The table shows that model explain the variations within the panels to be about $44.13 \%$ while between the panels the model explains the variations to be about $88.90 \%$ and the remainder is as a result of uncaptured factors and panels.

The overall $R^{2}$ is $76.05 \%$ thus implying that the three forms of shareholding captured in the revised conceptual framework significantly explain the effect of ownership structures on the financial performance as measured by the return on assets of the manufacturing firms while factors outside the final model and the revised conceptual account for $23.95 \%$. The overall model is considered significant and reliable based on the $\mathrm{P}$ value of $c h i^{2}$ of 0.000 which is below the threshold of 5\% hence we reject the null hypothesis that the model is not significant. The model output indicates that holding all other factors constant, a rise in one unit in foreign shareholding led to decrease in returns on assets by 1.08 units however this is inconclusive since the confidence interval range seems to swing between a positive effect and a negative effect. Institutional shareholding has a negative effect on returns on assets. This is based on the fact that ceteris Paribas a rise in one unit of institutional shareholding leads to a decrease in returns on assets by 4.12 units this is conclusive since the confidence interval is negative. Lastly individual shareholding has positive effect on the returns on assets and is very significant. A rise in individual shareholding by one unit leads to rise in returns on assets by 2.17 units. The model argues that holding the ownership structures constant namely, the foreign, individual and institutional shareholding, returns on assets increases by 2.34 units however all this changes in the coefficients are across time and contains between and within effects of the panels.

\subsection{Conclusions and Recommendations}

\subsection{Conclusions}

This study concluded that ownership structures are key components of financial performance of listed manufacturers in Kenya. The model relating ownership structures and financial performance had high significance. The study concludes that the variables are significant in influencing the financial performance as measured by the returns on the asset. Board shareholding effects was inconclusive since it was not analysed to conclusion, foreign shareholding has mixed effect on financial performance of the manufacturing firms. Institutional shareholding on the other hand has negative significant on the returns on assets while individual shareholders have positive effect on return on assets. In this case therefore, it is concluded that financial performance as measured by returns of Assets for listed manufacturers in Kenya is significantly influenced by the share of institutional and individual ownership structures and insignificantly by the share of foreign shareholding though not conclusive.

\subsection{Recommendations}

This study recommends that listed entities need to adopt dispersed shareholding structures as this study has revealed that ownership structures mixed effects on the financial performance of listed manufacturing firms as measured by the returns on assets. From the study findings the 
International Journal of Current Aspects in Finance, Banking and Accounting, Volume 4, Issue 1, 2022 PP 35-55, ISSN 2707-8035

effects of board shareholding did not materialize due to correlation effects. However, boards contribute heavily to the financial performance of listed manufacturing firms and as such further review of board shareholding and its effect on the financial performance should be investigated further in order to determine the optimum board shareholding ratio or share for optimum returns on asset.

The study indicates that the effect of foreign shareholding on the returns on assets is inconclusive and is highly volatile therefore further studies on this variable can be tested with other firms listed in the NSE or Listed manufacturing firms within the region in order to get a conclusive effect. However, it is advisable for the listed manufacturing firms that they maintain the optimum foreign shareholding that will not reduce the returns on assets. It's also advisable to maintain foreign shareholding to the extent that is within the perquisites of the law to avoid silent takeovers of local manufacturing firms by the dominant foreign shareholders. The institutional shareholding was found to have a negative significant effect and had the highest negative significant effect on returns on assets as compared to other variables. This could be attributed by the freight of returns as the institutional shareholders claims for huge dividends due to their massive capacity to provide capital and equity. It's therefore that institutional shareholding maintained at the most optimum level. However, it's prudent to note that institutional shareholding provide capital which may not be easy to raise from individual shareholding hence the need to strike a balance between the two. Lastly it was found out that individual shareholding has positive and significant effect on the returns on assets, therefore it's advisable that firms increase individual shareholding in their ownership structures since it improves the returns on assets significantly. Additionally, the individual shareholding is cheap and an easier way to raise equity as compared to the other forms of shareholding. Finally manufacturing firms in Kenya should diversify shareholding since it is likely to improve financial performance.

\section{References}

Abbasi, A., \& Malik, O. A. (2015). Firms' size moderating financial performance in growing firms: An empirical evidence from Pakistan. International Journal of Economics and Financial Issues, $5(2), 334-339$.

Abonazel, M. R. (2018). Different estimators for stochastic parameter panel data models with serially correlated rrrors. Journal of Statistics Applications \& Probability, 7(3),423-434.

Abrigo, M., \& Inessa, L. (2016). Estimation of Panel Vector Autoregression in Stata. The Stata Journal ; Promoting Communications on Statistics and Stata, 16(3),778-804.

Adamu, A., \& Haruna, J. (2020). Ownership structures and firm performance in Nigeria:a canonical correlation analysis. Journal of Research in Emerging Markets, 2(4),22-32.

Alabdullah, T. Y. (2018). The relationship between ownership structure and firm financial performance: Evidence from Jordan. Benchmarking: An International Journal, 25(1),319-333.

Albasu, J., \& Nyameh, J. (2017). Relevenance of stakeholders theory, organisation identity theory and social exchange theory to corporate social responsibility and employees performance in commercial banks in Nigeria. International Journal of Business, Economics and Management, $4(5), 95-105$.

Anatolyev, S., \& Mikkel, S. (2021). Testing many restrictions under heteroskedasticity. Econometrics, $1-68$.

Arvanitis, S. (2018). A note on stable limit theory for the OLSE with non usual rates and the heteroskedasticity robust Wald test. Communications in Statistics - Theory and Methods, $47(1), 28-41$. 
International Journal of Current Aspects in Finance, Banking and Accounting, Volume 4, Issue 1, 2022 PP 35-55, ISSN 2707-8035

Aza, I. E. (2018). Influence of firm size on financial performance of deposit money banks quoted on the Nigeria stock exchange. International Journal of Economics and Financial Research, 4(9),297-302.

Baltagi, B., \& Liu, L. (2015). Random and fixed effects spatial two-stage least squares estimators for the generalized mixed regressive spatial autoregressive panel data mode. Econometric Reviews , 35(4), 638-658.

Barnabe, W., \& Ming, H. (2020). Technical efficiency and technology gap of the manufacturing industry in China: Does firm ownership matter? World Development, 127(1),104769.

Barney , J. (1991). Firm resources and sustained competitive advantage. Journal of Management, 17 (1), 99-120.

Bender, J., Wahl, T., \& Jensen, J. (2014). Multivariate design in the presence of non-stationarity. Journal of Hydrology, 514(1),123-130.

Beneito, P., Maria, E., \& Amparo, L. (2015). Ownership and the cyclicality of firms' R\&D investment. International Entrepreneurship and Management Journal, 11(1),343-359.

Bianco, M., \& Casavola, P. (2016). Italian corporate governance: Effects on financial structure and firm performance. European Business Review, 43(1),1057-1069.

Bjurstrom, H. K., \& Schillemans, T. (2020). Trust and verification: balancing agency and stewardship theory in the governance of agencies. International Public Management Journal, 23(5),650676.

BOC kenya. (2020). 2019 Annual report. Nairobi: BOC Kenya.

Bollen, K., \& Brand, J. (2010). A General panel model with random and fixed effects: A structural equations approach. Social Focus, 89(1),1-34.

Brahmadev, P., \& Leepsa, N. M. (2017). Agency theory: Review of theory and evidence on problems and perspectives. Indian Journal of Corporate Governance, 10(1),74-95.

Bromiley, P., \& Rau, D. (2016). Operations management and the resource based view: Another view. Journal of Operations Management, 41(1),95-106.

Burke, J., \& Schoonenboom, J. (2017). How to construct a mixed methods research design. KZfSS Kölner Zeitschrift für Soziologie und Sozialpsychologie, 69(1),107-131.

Cain, M., Zhang, Z., \& Yuan, H. K. (2017). Univariate and multivariate skewness and kurtosis for measuring nonnormality: Prevalence, influence and estimation. Behavior Research Methods volume, 49(1), 1716-1735.

Capital Markets Authority. (2019). Mumias Sugar Annual Report. Nairobi: Mumias Sugar.

Carney, M., Estrin, S., Liang, Z., \& Shapiro, D. (2019). National institutional systems, foreign ownership and firm performance: The case of understudied countries. Journal of World Business, 54(4),244-257.

Cazurra, A. C., Mudambi, R., \& Pedersen, T. (2019). Subsidiary power: Loaned or owned? The lenses of agency theory and resource dependence theory. Global Strategy Journal, 9(4),491-501.

Chandrasena, S. M., \& Kaluthunga, K. M. (2015). An empirical study on corporate ownership structure and firm performance: Evidence from listed companies in Sri Lanka. 6th International Conference on Business \& Information ICBI - 2015 (pp. 67-77). Sri Lanka: Faculty of Commerce and Management Studies, University of Kelaniya.

Chih-Hai, Y., \& Huang, C. (2016). Ownership, trade, and productivity in Vietnam's manufacturing firms. Asia-Pacific Journal of Accounting \& Economics, 23(3),356-371. 
International Journal of Current Aspects in Finance, Banking and Accounting, Volume 4, Issue 1, 2022 PP 35-55, ISSN 2707-8035

Chrisman, J. (2019). Stewardship theory: Realism, relevance, and family firm governance. Entrepreneurship Theory and Practice, 43(6),1051-1066.

Chung, Y. S., \& Robert, M. (2019). An augmented autoregressive distributed lag bounds test for cointegration. Economic Modelling, 80(1),130-141.

Cooper, D., \& Schindler, P. (2014). Business Research Methods. Boston: Macgraw-Hill/Irwin.

Creswell, J. (2013). Qualitative inquiry \& research design: Choosing among five approaches (3rd ed.). California: Thousand Oaks.

Daoud, J. (2017). Multicollinearity and regression analysis. Journal of Physics: Conference Series, 89.

Darko, J., Aribi, Z. A., \& Uzonwanne, G. C. (2016). Corporate governance: the impact of director and board structure, ownership structure and corporate control on the performance of listed companies on the Ghana stock exchange. Corporate Governance, , 16(2),259-277.

Davis, J. H., Shoorman, F. D., \& Donaldson, L. (1997). Toward a stewardship theory of management. Academy of Management Review, 22(1), 20-47.

Davis, J., \& Donaldson, L. (1991). Stewardship theory or agency theory: CEO governance and shareholder returns. Australian Journal of Management, 16(1),49-64.

Ducassy, I., \& Guyot, A. (2017). Complex ownership structures, corporate governance and firm performance: The French context. Research in International Business and Finance, 39(A),291306.

Ernesto, L. V., Jacobo, G. C., \& Teresa, F. (2016). Firm size and financial performance: Intermediate effects of indebtedness. Agribusiness, 32(4),454-465.

Eveready East Africa. (2020, July 06). Eveready Annual Report. Retrieved from Eveready Ready East Africa PLC: http://eveready.co.ke/site/wp-content/uploads/2020/01/EEA-PLC-FY2019Financials.pdf

Eyigere, A. (2018). Influence of firm size on financial performance of deposit money banks. International Journal of Economics and Financial Research, 4(9),297-302.

Farooque, A., Buachoom, O., \& Sun, L. (2019). Board, audit committee, ownership and financial performance - emerging trends from Thailand. Pacific Accounting Review, 32(1),54-81.

Feng, Z., Wei, L., \& Zhu, Y. (2018). Roles of Relationships Between large shareholders and managers in radical innovation: A stewardship theory perspective. The Journal of Product Management, 35(1),88-105.

Fonseca, L., Ramos, A., Rosa, A., Braga, A., \& Sampaio, P. (2016). Stakeholders satisfaction and sustainable success. International Journal of Industrial and Systems Engineering, 24(2), 43-51.

Foyeke, O. I., Ihoya, F. O., \& Ojeka, S. (2015). Firm Size and Financial performance: A determinant of corporate governance disclosure practices of Nigerian companies. Journal of Accounting and Auditing: Research \& Practice, 1(1),1-8.

Frame Tree Group. (2020). Annual Report. Nairobi: Frame Tree Group.

Freeman, R. E. (1984). Strategic Management; A stakeholder approach. Boston: Pitman Publishing Inc.

Gaur, A., \& Delios, A. (2015). International diversification of emerging market firms: The role of ownership structure and group affiliation. Management International Review, 55(1),235-255.

Gichohi, R. (2018). Relationship between ownership structure and financial performance of companies at the NSE in kenya. KCA university Masters Thesis, unpublished, 1-64. 
International Journal of Current Aspects in Finance, Banking and Accounting, Volume 4, Issue 1, 2022 PP 35-55, ISSN 2707-8035

Gugong, B. K., Arugu, L., \& Dangago, K. I. (2014). Impact of ownership structure on the financial performance of listed insurance firms in Nigeria. International Journal of Academic Research in Accounting, Finance and Management Sciences, 4(1),409-416.

Gurbuz, A. O., \& Aybars, A. (2010). The impact iof foreign ownership on firm performance,evidence from an emerging market:Turkey. American journal of economics and business administration, 2(4),350-359.

Gurusamy, P. (2017). Board characteristics, audit committee and ownership structure influence on firm performance of manufacturing firms in India. International Journal of Business and Economics Research, 6(4),73-87.

Hitt, M. A., Xu, K., \& Carnes, C. M. (2016). Resource based theory in operations management research. Journal of Operations Management, 41(1),77-94.

Jensen, M. C., \& Meckling, W. H. (1976). Theory of the Firm: Managerial Behavior, Agency costs and Ownership Structure. Journal of Financial Performance, 3(4),305-306.

Kao, M. F., Hodgkison, L., \& Jaafar, A. (2019). Ownership structure, board of directors and firm performance: evidence from Taiwan. Corporate Governance, 19(1),189-216.

Kartikasari, D., \& Merianti, M. (2016). The effect of leverage and firm size to profitability of public manufacturing companies in Indonesia. International Journal of Economics and Financial Issues, 6(2), 409-413.

Keay, A. (2017). Stewardship theory: is board accountability necessary. International Journal of Law and Management, 59(6),1292-1314.

Kellermans, F., Walter, J., Crook, R., \& Narayanan, V. (2016). The resource-based view in entrepreneurship: A content-analytical comparison of researchers' and entrepreneurs' views. Journal of Small Business Management, 54(1),26-48.

Kobuthi, E., K'Obonyo, P., \& Ogutu, M. (2018). Corporate governance and performance of listed firms on the Nairobi Securities Exchange. International Journal of Scientific Research and Management, 6(1),7-17.

Kochen, S. (2014). Topics in the theory of definition. The Theory of Models, 170-176.

Krishnaswamy, O. R., \& Satyaprasad, B. G. (2010). Business Research Methods. Mumbai, India: Himalaya Publishing House.

Kristen, J. (2015). Stakeholders theory- how they influence the business policy. Scholedge International Journal of Business Policy \& Governance, 2(4),14-17.

Lekaram, V. (2014). The relationship of corporate governance and financial performance of manufacturing firms listed in the Nairobi securities exchange. International Journal of Business and Commerce, 3(12),30-57.

Lin, W., Cheah, J. W., Azali, M., Ho, J., \& Yip, N. (2019). Does firm size matter? Evidence on the impact of the green innovation strategy on corporate financial performance in the automotive sector. Journal of Cleaner Production, 229(1),974-988.

Malla, P. (2013). Corporate governance: concept, evolution and India story. New Delhi: Routledge.

Mandala, N., Kaijage, E., Aduda, J., \& Iraya, C. (2018). An Empirical Investigation of the relationship between board structure and performance of financial insititution in Kenya. Journal of Finance and Investment Analysis, 7(1),37-57.

Mansur, H., \& Tangl, A. (2018). The effect of corporate governance on the financial performance of listed companies in Amman Stock Exchange in Jordan. Journal of Advanced Management Science, 6(2),97-102. 
International Journal of Current Aspects in Finance, Banking and Accounting, Volume 4, Issue 1, 2022 PP 35-55, ISSN 2707-8035

McNown, R., Sam, C. Y., \& Goh, S. K. (2018). Bootstrapping the autoregressive distributed lag test for cointegration. Applied Economics, 50(13),1509-1521.

Meijer, E., Ockowski, E., \& Wansbeek, T. (2021). How measurement error affects inference in linear regression. Empirical Economics, 60(1),131-155.

Melo, P. S., \& Kibria, B. M. (2020). On Some Test Statistics for testing the regression coefficients in presence of multicollinearity: A simulation study. Stats, 3(1), 40-55.

Mihai, O., \& Cosmin, M. (2013). The impact of foreign ownership on the performance of Romanian liste manufacturing companies. The International Journal of Management Science and Information Technology, 106-123.

Mike, P., \& Andreas, K. (2017). Entrepreneurial behaviour, firm size and financial performance: the case of rural tourism family firms. Tourism Recreation Research, 43(1),2-14.

Minichilli, A., Brogi, M., \& Calabro, A. (2016). Weathering the storm: family ownership, governance, and performance through the financial and economic crisis. Corporate Governance, 24(6),552568.

Mishra, P., Pandey, C., Singh, U., Gupta, A., Sahu, C., \& Keshri, A. (2019). Descriptive statistics and normality tests for statistical data. Ann Card Anaesth, 22(1),67-72.

Mishra, R., \& Kapil, S. (2017). Effect of ownership structure and board structure on firm value: evidence from India. Corporate Governance, 17(4),700-726.

Mollah, S., Karim, W., \& Faroouque, O. (2012). Ownership structure, corporate governance and firm performance: Evidence from an African emerging market. Studies in Economics and Finance, 29(4),301-319.

Mudi, O. L. (2017). Ownership structure and financial performance of firms listed at the Nairobi securities exchange. University of Nairobi Masters Thesis, 1-58.

Muhindi, K. A., \& Ngaba, D. (2018). Effect of firm size on financial performance on banks: Case of commercial banks in Kenya. International Academic Journal of Economics and Finance, 3(1), 175-190.

Nair, A., \& Bhatacharya, S. S. (2019). Mandatory corporate social responsibility in India and its effect on corporate financial performance: Perspectives from institutional theory and resource-based view. Business Strategy and Development, 2(2),106-116.

Nairobi Securities Exchange. (2021, February 19). Listed companies. Retrieved from Nairobi Securities Exchange Web site: https://www.nse.co.ke/listed-companies/list.html?start=50

Ndiba, C. N. (2016). Effect of ownership structure on financial performance of sugar manufacturing firms in Kenya. Unpublished University of Nairobi Masters Thesis, 1-67.

Niresh, J. A., \& Velnampy, T. (2015). Firm size and profitability: A study of listed manufacturing firms in Sri Lanka. International Journal of Business and Management, 9(4), 57-67.

Omesi, I., \& Ogaluzor, O. (2019). Ownership structure and financial performance of listed consumer goods manufacturing companies in Nigeria. Journal of Accounting Information and Innovation, $5(1), 5-29$.

Parker, D. W., Dressel, U., Chevers, D., \& Zeppetella, L. (2018). Agency theory perspective on publicprivate-partnerships: international development project. International Journal of Productivity and Performance Management, 67(2),239-259.

Pervan, M., Pervan, I., \& Curak, M. (2017). The influence of age on firm performance: Evidence from Croatian Food Industry. Journal of Eastern Europe Research in Business and Economics, 2(5),23-43. 
International Journal of Current Aspects in Finance, Banking and Accounting, Volume 4, Issue 1, 2022 PP 35-55, ISSN 2707-8035

Phung, D. M., \& Mishra, A. V. (2016). Corporation diversification and firm performance: Evidence from Vietnamese listed firms. Australian Economic Papers, 55(1),386-408.

Phung, D. N., \& Mishra, A. V. (2016). Ownership structure and firm performance: Evidence from Vietnamese listed firms. Australian Economic Journal, 55(1),63-98.

Plitcha, J. (2019). The co-management and stakeholders theory as a useful approach to manage the problem of overtourism in historical cities - illustrated with an example of Krakow. International Journal of Tourism Cities, 5(4),685-699.

Saidu, S., \& Gidado, S. (2018). Managerial ownership and financial performance of listed manufacturing firms in Kenya. The International Journal of Academic Research in Business and Social Sciences, 8(9), 41-53.

Schillemans, T., \& Bjurstrom, K. H. (2020). Trust and verification: balancing agency and stewardship theory in the governance of agencies. International Public Management Journal, 23(5),650676.

Serfling, K., \& Juan, D. (2014). The twin agency problems in corporate finance - On the basis of Stulz's theory. Research Gate Journal.

Shampy, K., Goyal, P., \& Rahman, Z. (2015). A resource-based view on marketing capability, operations capability and financial performance: An empirical examination of mediating role. Procedia-Social and Behavioral Sciences, 189(1),406-415.

Simiyu, E., \& Too, I. C. (2018). Firms characteristic and financial performance of general insurance firms in Kenya. International Journal of Business Management \& Finance, 1(39), 672-689.

Stanley, M. (2007). International Corporate Governance. Journal of Applied Corporate Fiance .

Strulz, R. (1988). Managerial control of voting rights; financing policies and the market for corporate control. Financial Journal of Economics, 20(1),25-54.

Taherdoost, H. (2017). Determining sample size; How to calculate survey sample size. International Journal of Economics and Management Systems, 2(1),237-239.

Tamene, E. (2016). Theorizing conceptual framework. Asian Journal of Educational Research, 4(2),5056.

Tariq, T. Y. (2018). The relationship between ownership structure and firm financial performance: Evidence from Jordan. Benchmarking: An International Journal, 25(1),319-333.

Thai, H. M., \& Kabir, R. (2017). Does corporate governance shape the relationship between corporate social responsibility and financial performance? Pacific Accounting Review, 29(2),227-258.

Vitolla, F., Raimo, N., \& Michele, R. (2020). Board characteristics and integrated reporting quality: an agency theory perspective. Corporate Social Responsibility and Environment, 27(2),11521163.

Vu, M. C., Phan, T. T., \& Le, N. T. (2018). Relationship between board ownership structure and firm financial performance in transitional economy:the case of Vietnam. Research in International Business and Finance, 45,512-528.

Wang, J., \& Wang, X. (2015). Benefits of foreign ownership: Evidence from foreign direct investment in China. Journal of International Economics, 97(2),325-338.

Wangtao, Y., Roberto, C., Mark, J., \& Feng, M. (2018). Data-driven supply chain capabilities and performance: A resource-based view. Transportation Research Part E: Logistics and Transportation Review, 114(1),371-385. 
International Journal of Current Aspects in Finance, Banking and Accounting, Volume 4, Issue 1, 2022 PP 35-55, ISSN 2707-8035

Yusuf, F., Yousaf, A., \& Saeed, A. (2018). Rethinking agency theory in developing countries: A case study of Pakistan. Accounting Forum, 42(4),281-292.

Zhaoyang, G., \& Udaya, K. (2012). Corporate governance and firm performance of listed firms in Sri Lanka. Procedia - Social and Behavioral Sciences, 40(1),664-667.

Zhou, K., Gao, G. Y., \& Hongxin, Z. (2016). State ownership and firm innovation in China: An integrated view of institutional and efficiency logics. Administrative Science Quarterly, 62(2),375-404.

This is an open-access article published and distributed under the terms and conditions of the (c) (7) (5) Creative Commons Attribution 4.0 International License of United States unless otherwise stated. Access, citation and distribution of this article is allowed with full recognition of the authors and the source. Copyright, content ownership and liability for content herein remain with the authors. 